\title{
Intellectual disability-cataracts-kyphosis syndrome
}

INSERM

\section{Source}

INSERM. (1999). Orphanet: an online rare disease and orphan drug data base. Intellectual disability-cataracts-kyphosis syndrome. ORPHA:171860

This syndrome is characterized by severe intellectual deficit, kyphosis with onset in childhood and cataract with onset in late adolescence. 